\title{
STIMULASI TITIK REPRODUKSI DENGAN LASERPUNKTUR SEMIKONDUKTOR TERHADAP PENAMPILAN BIRAHI SAPI BALI (Bos sondaicus)
}

\section{THE STIMULATION OF REPRODUCTION PONT WITH A SEMICONDUCTOR LASERPUNCTURE TO ESTROUS SYNCHRONIZATION OF BALI CATTLE (Bos sondaicus)}

\author{
Hanifah Khairun Nisa 1), Budiarto 2), R. Tatang Santanu Adikara 2), Herry Agoes \\ Hermadi 2), Soeharsono 2), Imam Mustofa ${ }^{2)}$ \\ 1) Mahasiswa, 2) Dosen \\ Fakultas Kedokteran Hewan Universitas Airlangga \\ Kampus C UNAIR, Jl. Mulyorejo-Surabaya 60115 \\ Telp. 031-5992785, Fax. 031-5993015 \\ Email: jbmvunair@gmail.com
}

\begin{abstract}
This research to know the stimulation of reproduction point with a semiconductor laserpuncture to estrous synchronization of Bali Cattle was conducted in Loka Penelitian Sapi Potong Grati-Pasuruan, East Java. Estrous synchronization is a technique to get the sign of estrous and ovulation (estrous outside of estrous cycle) to be easier to detect estrous, synchronization of breeding, and shorter of calving interval. Laserpuncture was applied on 8 head bali cattles at 14 reproduction acupuncture points, 10 second for each point, 3 times frequency with interval 1 day (20-24 times). The variabel of this assessment were respons and signs of estrous, synchronized of estrous with Chi square test and T-test method. Result showed that there was significant correlation between semiconductor laserpuncture with estrous synchronization $(p \leq 0,05)$. The result of assessment $8(100 \%)$ head bali cattle was estrous. The respons of estrous appeared 1 head $(12,5 \%)$ on $5^{\text {th }}$ day $\left(4^{\text {th }}\right.$ day post laserpuncture), 4 head $(50 \%)$ on $6^{\text {th }}$ day $\left(5^{\text {th }}\right.$ day post laserpuncture) 1 head $(12,5)$ on $8^{\text {th }}$ day ( $7^{\text {th }}$ day post laserpuncture), and 2 head $(25 \%)$ on $10^{\text {th }}$ day (9th day post laserpuncture). This result showed that semi conductor laserpuncture technology was effective to stimulate estrous synchronization and resulting ovulation, with the evidence that conception was occurred.
\end{abstract}

Key words: Bali Cattle, semi conductor laserpuncture, estrous synchronization

\section{PENDAHULUAN}

Berdasarkan data statistik Dinas Peternakan Propoinsi Jawa Timur pada tahun 2017 populasi ternak sapi potong di Indonesia sejumlah 16.599.247. Populasi sapi potong yang berada di propinsi Jawa Timur mengalami peningkatan sebesar 3,79\% dari tahun 2016 sebesar 4.407.807 menjadi 4.545.780 tahun 2017 (DITJENAK, 2017). Sapi potong merupakan salah satu ternak ruminansia yang mempunyai kontribusi terbesar sebagai penghasil daging serta untuk pemenuhan kebutuhan pangan khususnya protein hewani (Direktorat
Jendral PKH, 2017). Daging sapi merupakan salah satu pangan penghasil protein hewani.

Daging sapi berkontribusi 19,2\% terhadap total produksi daging nasional, namun ketersediaan jumlah sapi potong di Indonesia belum dapat memenuhi kebutuhan pangan nasional (Data Statistik Ditjen PKH, 2017).

Salah satu jenis ternak di Indonesia yang cukup untuk menghasilkan daging adalah sapi Bali. Jenis sapi ini sudah banyak dikembangkan oleh masyarakat untuk digemukkan (penghasil daging), sebagai sumber pupuk, tenaga kerja, 
tambahan pendapatan, tabungan dan penyediaan lapangan kerja (Hafid, 2009). Performa sapi Bali mempunyai adaptasi yang baik terhadap pengaruh lingkungan yang panas dan cukup toleran terhadap lingkungan dingin serta sangat efisien dalam penggunaan pakan dengan kualitas rendah (Darmadja, 1980).

Industri Peternakan sapi Bali memiliki masalah yaitu estrus ternak yang tidak seragam dan tidak terdeteksi, hal tersebut menyulitkan pengamatan dan tatalaksana perkawinan sehingga reproduktivitas menjadi rendah. Untuk mengatasi hal tersebut perlu dilaukan induksi atau sinkronisasi estrus. Kendala dari program tersebut adalah mahalnya harga preparat homon yang diperlukan, sehingga bagi peternak kurang ekonomis. Substansi yang sering digunakan untuk induksi estrus adalah prostaglandin yang merupakan substansi sejenis hormone yang dihasilkan oleh hampir seluruh sel dan jaringan tubuh. Prostaglandin memiliki peran penting dalam pengaturan berbagai proses metabolisme seluler (Ensminger, 1974).

Salah satu teknologi alternatif untuk gertak birahi dengan memanfaatkan teknologi akupunktur. Stimulasi dengan laser atau disebut juga dengan laserpunktur adalah teknik menembakkan laser pada titik akupunktur sebagai reseptor biologi dalam tubuh makhluk hidup. Penggunaan laser untuk menimbulkan stimulasi pada titik akupunktur hanya membutuhkan waktu beberapa detik untuk tiap titiknya. Teknologi ini relatif murah, karena satu alat bisa digunakan secara masal dengan biaya operasional yang relatif murah (Fatimah, 2010). Hasil penelitian Herdis (2005) menyatakan bahwa, jika dilihat dai segi ekonomis tanpa menghitung biaya operator pelaksana, pemakaian laserpunktur dengan penembakan pada 17 titik reproduksi selama 20 detik pada tiga kali penembakan hanya memerlukan biaya sebesar Rp 3.000 per ekor domba, sedangkan sesuai dengan harga pasar penggunaan PGF $2 a$ per ekor domba bisa mencapai Rp 50.000 dan per ekor sapi, kerbau, kuda mencapai Rp 90.000.

Meningat posisi sel-sel reseptor berada di bawah kulit, maka untuk ternak yang kulitnya tebal seperti sapi dan kerbau diperlukan intensitas sinar yang lebih kuat untuk stimulasi. Hasil ujilaboratorium menujukkan bahwa sinar laser dengan kekuatan 70mWatt mampu meningkatkan sel-sel reseptor ternak besar (Adikara, 1995).

Berdasarkan pertimbangan diatas, maka perlu dilakukannya penelitian tentang stimulasi titik reproduksi dengan laserpunktur semikonduktor terhadap penampilan birahi sapi Bali.

\section{MATERI DAN METODE PENELITIAN}

\section{Bahan dan Sampel Penelitian}

Bahan yang digunakan pada penelitian ini berupa sapi Bali (Bos sondaicus) betina sejumlah 8 ekor dalam keadaan sehat. Sapi Bali betina yang digunakan pada penelitian ini juga dilakukan pengecekkan terlebih dahulu dengan menggunakan Ultrasonografi (USG) untuk melihat sapi berada pada fase luteal dan tidak dalam keadaan bunting. Bahan lain yang digunakan adalah kamera, kalung tanda pengenal sapi, glove, vasellin, alkohol $70 \%$ dan tali.

\section{Persiapan Penelitian}

Sapi Bali untuk penelitian ini adalah sapi Bali yang telah berumur 4-5 tahun yang dalam keadaan sehat, sudah dewasa kelamin (dara atau pernah beranak), berada pada fase luteal dipilih secara acak tanpa melihat siklus birahinya, terjaga kondisinya dengan pemberian pakan dan minum yang baik, sapi Bali tidak dalam keadaan sakit, 
serta dengan melihat adanya kebuntingan pada sapi Bali dengan menggunakan alat Ultrasonografi (USG).

\section{Titik Reproduksi Sapi Betina}

Titik reproduksi akupunktur yang berhubungan dengan gertak birahi atau super-ovulasi yaitu menggunakan kemampuan 10 hingga 50 mWatt yang ditembakkan pada titik reproduksi. Titik penembakan yang pertama yaitu pada titik estrus yaitu titik Ming-men GV-4 (tunggal) terletak didaerah dorsal dari persendian $\mathrm{V}$. Lumbal II-III (sebagai general point). Rangsangan pada titik ini akan meningkatkan aktivitas dari kelenjar hipofisa.

Titik penembakan yang kedua yaitu titik ovarium atau titik Bai-hui GV-2 (dexter et sinister) terletak di daerah dorsal antara processus transversarius dari V. Lumbal II dengan V. Lumbal III. Rangsangan pada titik ini meningkatkan aktivitas ovarium dalam hal pembentukan folikel dan pembentukan hormon reproduksi.

Titik penembakan yang ketiga yaitu pada titik oviduk (dexter et sinister) terletak di daerah dorsal antara processus transversus dari V. Lumbal III-IV-V-VI. Rangsangan ini pada titik ini dapat meningkatkan aktivitas oviduk.

Titik penembakan yang keempat adalah pada titik uterus (dexter et sinister) terletak di sisi dorsocranial dari os. Illium. Rangsangan pada titik ini dapat meningkatkan aktivitas uteus.

Dan titik penembakan yang kelima adalah titik hormonal (tunggal) terletak di daerah dorsal dari persendian sacro-coccygea. Rangsangan pada titik ini aka meningkatkan produksi hormone prostaglandin dari dalam tubuh.

\section{Prosedur Pelaksanaan Laserpunktur}

Pada laserpunktur semikonduktor diterapkan pada sapi Bali setiap hari mulai dari hari pertama penembkaan sampai terjadinya tanda birahi ada ternak. Penembakan dilakukan di titik reproduksi ternak sapi Bali dengan menggunakan alat laserpunktur semikonduktor yang diatur terlebih dahulu dengan dosis 0,5 joule dan power supply laser yang disetel sebesar 100 mWatt. Penembakan laserpunktur pada sapi Bali dilakukan setiap hari pada pukul 10.00 WIB.

\section{Pemeriksaan Penampilan Birahi}

Pemeriksaan dilakukan setiap hari untuk melihat adanya respon birahi sapi setelah dilakukan pada penembakan laserpunktur semikonduktor. Memantau gejala birahi disetiap harinya pada 8 ekor sapi Bali. Untuk melihat gejala birahi yang nampak langsung dengan seringnya sapi Bali melakukan buang air kecil, gelisah, serta melihat tanda-tanda birahi mulai dengan terdapat adanya perubahan warna vulva pada sapi menjadi warna merah dan hangat, keluarnya lendir dari kelenjar bartolini yang dapat dilihat setelah penembakan laserpunktur semikonduktor dalam waktu 3 hingga 7 hari atau sampai terlihat adanya tanda-tanda birahi pada sapi Bali.

\section{Analisis Data}

Data hasil penelitian ini untuk selanjutnya dilakukan uji statistik data kejadian birahi dengan menggunakan uji Chi square $\left(\mathrm{x}^{2}\right)$ pada tingkat kepercayaan (a) sebanyak 5\%. Data waktu kejadian timbulnya birahi (hari) pada sampel perlakuan stimulasi titik reproduksi dianalisis dengan menggunakan uji T-test dengan tingkat kepercayaan (a) sebanyak $5 \%$. 


\section{HASIL DAN PEMBAHASAN}

Penelitian ini dilakukan pada bulan Juli hingga September 2018 betempat di Loka Penelitian Sapi Potong Grati Pasuruan Jawa Timur. Stimulasi titik reproduksi dengan laserpunktur semikonduktor terhadap penambilan birahi sapi Bali di titik reproduksinya yang meliputi titik estrus atau GV-4 (Ming-men), titik puncak atau GV-2 (Bai- hui), titik ovarium atau BL-23 (Shen-shu), titik oviduk BL-24 (Qi hai shu), titik uterus BL-25 (Da chang Shu), titik serviks BL54 (Ba shan atau Zhi bian), dan titik ekstragenital atau vulva. Penembakan laserpunktur dilakukan selama 40 detik/titik setiap hari sampai sapi Bali mennjukkan adanya gejala birahi.
Didapatkan bahwa dari 8 ekor sapi Bali sampel yang digunakan pada penelitian ini menunjukkan adanya gejala birahi. Hasil pengamatan stimulasi titik reproduksi dengan laserpunktur terhadap delapan ekor sapi Bali memiliki tingkat keberhasilan sampai $100 \%$. Dapat dilihat pada gambar 1. Pada penelitian stimulasi titik reproduksi dengan laserpunktur semikonduktor terhadap penampilan birahi dapat juga dilihat waktu terjadinya birahi. Sebanyak 50\% sapi sampel yang digunakan menunjukkan birahi pada hari ke-6 setelah dilakukan penembakan laserpunktur pada titik reproduksinya selama lima kali perlakuan yang dilakukan dalam rentan waktu 24 jam. berturut-turut sebagai berikut:

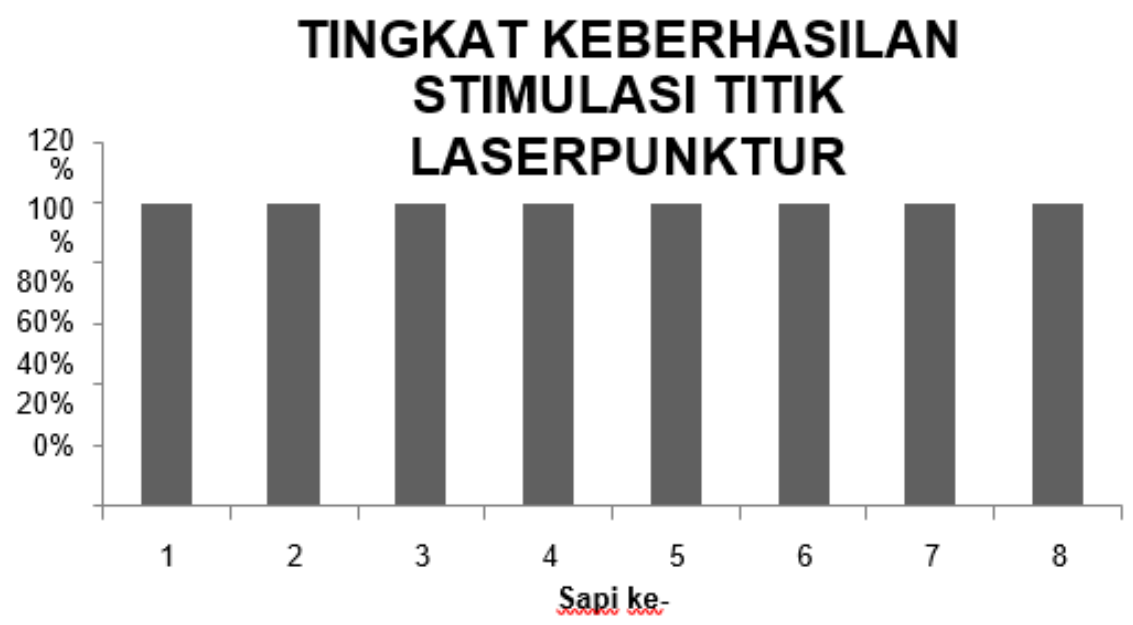

Gambar 1. Tingkat keberhasilan Stimulasi titik reproduksi.

\begin{tabular}{|c|c|c|c|c|c|c|c|c|}
\hline Sampel & Sapi 1 & Sapi 2 & Sapi 3 & Sapi 4 & Sapi 5 & Sapi 6 & Sapi 7 & Sapi 8 \\
\hline $\begin{array}{c}\text { Waktu Birahi } \\
\text { (hari ke -) }\end{array}$ & 6 & 6 & 8 & 10 & 10 & 5 & 6 & 6 \\
\hline $\mathrm{X}$ & & & & & & & & \\
\hline
\end{tabular}

Tabel 1. Rata-rata waktu kejadian birahi setelah perlakuan 
Analisis data yang digunakan dengan menggunakan uji Chi- square dan menggunakan uji T-test, menunjukkan adanya hubungan pemberian laserpunktur semikonduktor dengan kejadian birahi sapi Bali menunjukkan hasil yang signifikan dengan $(\mathrm{p} \leq 0,05)$ dan empat dari delapan $(50 \%)$ dari sampel yang digunakan menunjukkan timbulnya birahi pada hari ke-6 atau setelah dilakukan penembakan 5 kali pada titik reproduksinya dengan jangka waktu 24 jam setiap perlakuan.

Dari penelitian ini didapatkan hasil rata-rata waktu setelah dilakukan perlakuan yaitu 1 ekor (12,5\%) mengalami birahi hari ke-5 setelah 4 hari perlakuan, 4 ekor (50\%) mengalami birahi hari ke- 6 setelah 5 hari perlakuan, 2 ekor (25\%) mengalami birahi pada hari ke-8 setelah 7 hari perlakuan, dan 1 ekor $(12,5 \%)$ mengalami birahi pada hari ke-10 setelah

9 hari perlakuan. Perbedaan waktu timbulnya birahi pada 8 ekor sapi ini kemungkinan disebabkan karena respon setiap individu sapi Bali yang tidak sama dalam memenerima rangsangan setelah perlakuan. Jarak birahi yang terpanjang yaitu 2 hari (2448 jam).

Perbedaan relatif antar paritas induk dalam jumlah presentase intensitas estrus disebabkan karena perilaku estrus tersebut bergantung pada konsetrasi estrogen yang dieskresikan oleh folikel de graff saat estrus berlangsung. Secara normal akan terjadi peningkatan konsentrasi estrogen dan penurunan progesterone saat proestrus dan estrus berlangsung. Kondisi tersebut sangat di perngaruhi oleh faktor manajemen, lingkungan dan fisiologis induk sapi (Yoshida, 2006).

\section{KESIMPULAN}

Berdasarkan hasil penelitian tentang stimulasi titik reproduksi dengan laserpunktur semikonduktor terhadap penampilan birahi sapi Bali dapat disimpulkan bahwa delapan sapi Bali menunjukkan birahi dengan ratarata birahi pada hari ke-6 setelah dilakukan penembakan di titik-titik reproduksi. Tampilan birahi menunjukkan adanya keluaran lendir dari bagian vulva, vulya yang berwarna merah, lebam dan hangat, suara sapi yang bengah, ingin menungangi betina lain dan siap untuk dikawini oleh pejantan.

\section{DAFTAR PUSTAKA}

Adikara, R.T.S. 1995. Pemanfaatan Teknologi Akupunktur untuk Kesehatan dan Peningkatan Produktivitas pada Ternak Sapi dan Ayam. Kelompok Studi Ilmu Pengetahuan dan Teknologi Veteriner Fakultas Kedokteran Hewan. Universitas Airlangga. Surabaya. 2(2); 110-117.

Adikara. 2018. Laserpunktur Hewan. Suatu Metode Alternatif untuk Pengobatan dan Peningkatan Produktivitas Ternal. Fakultas Kedokteran Hewan Universitas Airlangga. Surabaya. 61-80.

Darmadja, S.G.N.D. 1980. Setengah Abad Peternakan Sapi Tradisional dalam Ekosistem Pertanian di Bali (Desertasi) Bandung: Program Pascasarjana. Universitas Padjajaran: 42-45.

Direktorat Jendral Peternakan dan Kesehatan Hewan. 2017.

Peternakan Ditjenak Kementrian Pertanian Republik Indonesia. Jakarta. DITJENAK. 33-34. 
Dijennak, Direktorat Jendral Peternakan. 2011. Buku Statistik Peternakan dan Kesehatan Hewan. Jakarta. Depertemen Pertanian. 63-78.

Ensminger, M.E. 1974. Beef Cattle Science. $4^{\text {th }}$ ed. The Intestate Printers and Publisher. Denville, Illinois. Bulletin No. 2127.

Guntoro, S. 1997. Pemanfaatan Sinar Laser Dalam Penggemukan Sapi Bali. Seminar Nasional Peternakan dan Veteriner. J. 941-942.

Hafid. H dan Rugayah N. 2009. Persentase Karkas Sapi Bali pada Berbagai Berat Badan dan Lama Pemuasaan Sebelum Pemotongan. Fakultas Pertanian. Universitas Haluelo. Kendari. 77- 85.
Herdis. 2006. Pemanfaatan Teknologi Laserpunktur Untuk Peningkatan Efisiensi Reproduksi Ternak Betina. Jurnal Sains dan Teknologi Indonesia. 8(1); 37-43.

Fatimah. 2010. Teknologi Laserpuncture untuk Peningkatan Produksi ternak. Available at http://www.poultryindonesi a.co m. [02 Maret 2018].

Pusat Kajian Sapi Bali. 2012. Sapi Bali Sumberdaya Genetik Asli Indonesia. Universitas Udayana, Bali.

Saputra, K. 2001. Fenomena Akupunktur Modern dan Efek Biologi Laser. Pusat Penelitian Bioenergi. Lembaga Penelitian Universitas Airlangga. University Press.

Yoshida, S. 2006. Physiological Aspect of Grain Yeald. Ann. Rev. Olant Physiol.23.437. 